\title{
Tendency Of Usage Of Social Media Tools By The Public Relations Practitioners: An Evaluation On Turkey's 500 Biggest Industrial Corporations
}

\author{
Feride AKIM \\ Assist. Prof., İstanbul University Public Relations and Publicity Department, ferakim@yahoo.com \\ Aybike PELENK ÖZEL \\ Assist. Prof., Kocaeli University, Public Relations and Publicity Department, aybikepelenk@gmail.com
}

\begin{abstract}
The interactive communication in the artificial environment has widened its limits with the usage of the social media tools and has become an inevitable element of the digital era. The usage of the tools such as social network sharing sites (Myspace, Facebook, Faceparty, Friendster), blogs, e-mail usage, intranet, video conferencing, forums, video sharing sites (such as Youtube), music sharing sites (Jamendo.com)], business network sites (Linedln, Xing, eAcademy), cooperative web sites (Wikipedia), instant message, vikis (vikipedia), podcasts, training materials sharing (Mozilla's spreadfirefox.com, Linux.org), social bookmarking, bookmarking sites ensuring its users to make online news, stories, music (Digg, del.icio.us, Newsvine, Mixx it, Reddit), personal publication (weblogs, twitter) which take place in the social media tools by the public relations practitioners gradually gains importance in terms of the public relations practitioners.

In this study, the place and importance of social media tools with regards to public relations and their role in creating a new public relations process are discussed. Accordingly, an online questionnaire form was prepared and sent via e-mail to the public relations practitioners. These public relations practitioners were determined through the survey results of "Turkey's Top 500 Industrial Enterprises 2011" which was conducted regularly by Istanbul Chamber of Industry (ISO). An assessment intended to identify the trends and reasons of use of social media tools by the public relations practitioners who work in the biggest companies of Turkey and their perceptions of social media and traditional media was made.
\end{abstract}

Keywords: social media, social media usage, social and pr 


\section{Introduction: The Concept of Social Media and Its Functions}

Social media is a concept used in common for the online tools and web sites which create mutual interactivity by giving the users the opportunity to share information, thought, interest and knowledge. In this sense, social media acts as an intermediary to build community and networking by encouraging participation and to be related to (Sayımer 2008: 123). Social media, in broader sense, can also be defined as the websites that are built upon Web 2.0 technologies and allows you to have a deeper social interaction, to form communities and to accomplish cooperation projects (Akar 2011: 17).

Organizations use social media for various reasons: to strengthen the identity and reputation of the organization intended for their target audiences, to establish and maintain interactivity with different groups, to obtain the ideas quickly about the organization, to reduce the market research expenditures, to create the opportunity of word of mouth marketing, to gain new customers, to promote brand awareness, to make the organization more visible in social media, to be able to compete with the competitors in this field, to follow their competitors, to inform the social stakeholders about the organizations' products and services, and about the innovations and developments that are related to the organization.

\subsection{Social Media Tools}

Prominent, gradually expanding and growing social media tools which gradually increase their popularity much more take place among the tools which are required to be importantly managed in the public relations applications. The social media tool and environments make an environment which ensures the interaction between the institution and the target group, in which its user is not exposed to the single directional communication, the Bi-directional communication can be ensured, the feedback is instantly obtained, which is also open to the sharing and usage of the third persons possible. Also, due to the fact that it has low cost usage feature, it is a media which the users gradually prefers much. The social media also provides an instant, direct, interactive and new communication environment in many application fields of the public relations. By this way, the public relations practitioners have an idea about the attitude, behavior and expectations of their new social shareholders that the online communities form and make contributions to the satisfaction of their needs. The main features of the social media tools and their importance to the public relations are listed below.

\subsubsection{Facebook}

Facebook was established in 2004 as a social web site which aims to make people communicate with friends and exchange information. Facebook is a web platform that allows the networking of students with the help of photos, blog messages (Facebook notes), personal profiles, friend groups, e-mails, guest-book entries (The Wall), and interest groups (Fuchs 2008: 188).

Recently, most of the companies have a Facebook page. Through Facebook, companies publicize their products and services, in addition to this they share various albums, photographs and videos, inform consumers about the current developments and campaigns. 
At the same time, most of the companies establish communication with consumers via Facebook pages and by receiving problems, complaints and positive feedbacks they are able to provide with a mutual communication environment.

\subsubsection{Twitter}

Twitter is the leading micro-blogging site, allowing users to write short blogs of a maximum 140 characters. Despite its simple structure, users convey some information about themselves to their followers, give notifications about their situations and establish a direct form of communication. Through Twitter, what people talk about and the agenda can be followed at the same time (Brown 2009: 171-172). In terms of public relations applications, Twitter introduces an environment for the organizations to follow the attitudes, opinions and perceptions of their target audiences and an environment to produce solutions to the expectations and problems. The dialogues that take place between the followers and the organization, it's enabling of interaction, its instant and quick realization plays an important role for the sake of sharing the correct messages during crisis periods.

\subsubsection{Linkedln}

Linkedln formally launched in 2003. Linkedln had a total of 4,500 members in the network at the end of the first month in operation. As of March 31, 2012 professionals are signing up to join Linkedln at a rate of almost two new members per second. The company is publicly held and has a diversified business model with revenues coming from premium subscriptions, hiring solutions and marketing solutions (http://press.linkedln.com/about).

When it is evaluated from the point of view of public relations, LinkedIn is a carrier based professional web site; it communicates news and updates about the organization, it provides with information to the followers about the industry, experience, areas of expertise, seniority level, firm size, and help the followers to monitor the contents that they are interested in. With this aspect it helps organizations to perform a healthier target audience analysis in their works and in the campaigns that they conduct.

\subsubsection{Blogs}

Usage areas on the internet called weblogs or blogs which became increasingly popular are updated frequently and at the same time posts appear in reverse chronological order. Despite the claims that the first blog was established by Tim-Bernars-Lee in 1991, its recognition by a vast and large mass was realized in 1997 with the name "weblog" (Herring 2009).

The advances in information and communication technologies, widespread use of internet and the differentiation of its use, the awareness of the customers and their desire to have a say, the loss of websites' ease of use are among the reasons of blossoming of blogs (Akar 2006: 22). When it is evaluated within the public relations and general communication goals, blogs can be said to increase visibility and awareness of organizations and they contribute to the image of organizations. Corporate blogs aim at strengthening customer relations and building them on a solid basis. Blogs prevent the e-mail piles of organizations; therefore they help to increase the brainstorming of employees and give way to the emergence of creative 
new ideas (Alikılıç 2011: 26). Organizations can address a large customer portfolio cheaply or freely via blogs. They create an instant feedback process and update the content and spread this content with ease. Therefore they may create an effective interactive communication platform.

\subsubsection{Youtube}

YouTube, which was founded in 2005 by former employees of PayPal, is a web site that hosts videos. YouTube makes money by putting commercial ads on its site that accompany the videos. YouTube was bought by Google in 2006 (Fuchs 2008: 186-187). On Youtube, users can watch videos that are previously uploaded and they also upload their own videos. On this platform there are professional content, film and music videos alongside with private clips, parts from TV shows. Users can also comment on the videos that they watch.

When it is evaluated within the public relations and general communication goals, YouTube helps corporations to update their information about the corporate, products and services and share these information directly with the target audience, therefore it provides with an atmosphere of trust by creating a direct communication network. So that it helps the corporate to be preferred in the future and to gain respect in the long run.

\subsubsection{Flickr}

Flickr is a photograph sharing website developed by Ludicorp in 2004, and bought by Yahoo in 2005. Flickr has a structure that allows hosting, tagging and categorizing of photographs. The pictures that are uploaded to Flickr can be used easily by social networks like Facebook and Twitter, and by blogs and e-mails (http://www.flickr.com).

Bradley empasised that if the companies run events, they can encourage people to take photographs, post those to Flickr, create groups with associated discussions and, by use of the Creative Commons option, allow other people to use those images in their own presentations with an acknowledgement or link back to the companies (Bradley 2010: 250) At the same time, bloggers use Flickr if they want to allow their readers to click through to a higher resolution version of the image on their blog. Users can create 'photostreams' or slide shows of a specific collection of images (Brown 2009: 169).

\subsubsection{Xing}

Xing was established as a professional network that aims to make users to keep contact and exchange information with their university or business friends; that presents local events such as training courses, seminars, workshops and conferences; that informs about work assignments or projects, the latest jobs, or information about products and services; that provides with automatic job recommendations and the option to create job alerts and make profiles available to recruiters (http://www.xing.com/tr). Xing, which is a carrier based professional business network, makes contributions to the organizations in various ways: to announce news and updates related to the organization; to establish business connections; to examine business ads, firms and firm profiles; to get information about its followers' sector, their experience, areas of expertise, level of seniority, and etc. With this aspect it helps 
organizations to perform a healthier target audience analysis in their works and in the campaigns that they conduct.

\subsubsection{Forums}

Forums can be defined as online chat environments where people exchange their ideas by either opening new headings or sending messages to the previous headings. In the aforementioned environments, members usually follow conversations by connecting to the website. In forums individuals may converse and share according to their areas of interest through various headings or different headings under tags (Alikıliç 2011: 41). Therefore forums are sites that provides with exchange of information and ideas around private interests (Akar 2011: 17).

Forums, which are different than Wiki's and blogs, are supervised by administrators and discussions are made within certain rules (Öymen, Dikmen 2011: 164). These environments provide with two important advantages to public relations practitioners. The first one is that it provides with information about what stakeholders think, feel about the corporation that it represents, their attitudes and behaviors; the second one is that it provides with quick and honest responses to what it learns (Alikılıç 2011: 45). Therefore corporations gain the opportunity to know their stakeholders and to edit their messages in a healthier way. The stakeholders, whose comments are followed and replied, and whose problems are solved, would feel that they are respected and they get the chance to have a positive impression about the corporation.

\subsection{Social Media and Public Relations}

The applications of public relations in social media environment are defined as PR 2 (Özgen 2012: 11). It is possible to perform several applications related to public relations and advertising in social network sites, where target audience are together and where several information about the target audience can be obtained digitally. It is possible to use the social network sites as a public relations tool as listed below (Onat, Aşman Alikılıç 2008: 11341135):

1. The monitoring of corporate reputation should be done in social network sites by searching corporation's name, brand name, the names of the firms that form the corporate network, the names of senior executives and workers. Officers responsible for corporate communications can monitor which names appear in what way and with which profile content by typing the names in the search field.

2. In social network sites the rivals and related corporations' actions within the context of public relations should be examined and these environments should be evaluated while making media-planning.

3. Public relations departments or public relations agencies should count users of social network sites as target audiences. It is possible for them to send messages designed with different contents according to different target groups which are determined by the groups or networks in social network sites. 
4. Corporations may announce sports, cultural and artistic events that they sponsored to the target audience. (E.g. The event application in Facebook).

5. It can also be used to announce events such as contests, workshops and trainings which can overflow the corporation.

6. It can also be used to publicize the social responsibility projects to related groups and to find support.

7. Within the scope of crisis management, social network sites can be used to publish corporate messages during and before the crisis.

8. An honest and healthier communication can be established and corporate messages can be circulated by finding and influencing the people (structure hole) that link different groups together in social networks.

9. Workers can be utilized for the publication of messages related to an activity, a campaign or related to the corporation itself. Messages can be published via workers profiles. Especially workers in the training and marketing departments whose social networks both in real life and in social network sites are large, messages related to public relations may be published to very large masses.

\section{The Survey}

\subsection{The Aim of the Survey}

In this study, the importance of social media tools for public relations and their role in creating a new public relations process are discussed. In this study, it is intended to identify the trends and reasons of use of social media tools by the public relations practitioners who work in the biggest companies of Turkey and to put forward their perceptions relating to social media and traditional media.

\subsection{The Method and Scope of the Survey}

In the scope of this survey, 500 corporations were selected according to the survey results of "Turkey's Top 500 Industrial Enterprises 2011" which was conducted regularly by Istanbul Chamber of Industry (ISO). 478 corporations (names 22 of them were not mentioned) out of 500 were called on the phone and asked if they had public relations or corporate communication departments. It is ascertained that 175 of the corporations (approximately $36.6 \%$ out of 478 corporations) have public relations practitioners, and each one of them were called on the phone and told about the survey and they were sent online questionnaires via e-mail. 66 public relations practitioners (37,7\%) gave feedback and participated in the online questionnaire in 33 days. The corporations and workers who participated in the survey are kept secret. 


\subsection{The Findings and Evaluation of the Survey}

The data obtained from the survey were entered into SPSS 17 (Statistical Package for Social Scienses) and the findings obtained from the frequency distributions are shown below.

\subsection{The Results of the Survey}

Table 1: Gender of the Participants

\begin{tabular}{|l|c|c|}
\hline Variable & Gender Distribution & Percent \\
\hline Woman & 50 & 75,8 \\
\hline Man & 16 & 24,2 \\
\hline Total & $\mathbf{6 6}$ & $\mathbf{1 0 0 , 0}$ \\
\hline
\end{tabular}

$75,8 \%$ were women and $24,2 \%$ were men among those who participate in the survey.

Table 2: Age of the Participants

\begin{tabular}{|l|c|c|}
\hline Variable & Age Distribution & Percent \\
\hline $18-22$ & 1 & 1,5 \\
\hline $23-27$ & 19 & 28,8 \\
\hline $28-32$ & 8 & 12,1 \\
\hline $33-37$ & 9 & 13,6 \\
\hline $38-42$ & 17 & 25,8 \\
\hline $43-47$ & 4 & 6,1 \\
\hline $48-52$ & 7 & 10,6 \\
\hline 53 and Above & 1 & 1,5 \\
\hline Total & 66 & $\mathbf{1 0 0 , 0}$ \\
\hline
\end{tabular}

The average age of the participants were between ages $23-27$ with $28,8 \%$. 25,8 \% were $38-42$, $13,6 \%$ were $33-37,12,1 \%$ were $28-32,10.6 \%$ were $48-52,6,1 \%$ were $43-47,1,5 \%$ ( 1 person each) shares equally the age range of $18-22$ and 53 and above.

Table 3: Education Level of the Participants

\begin{tabular}{|lcc|}
\hline Variable & Education Distribution & Percent \\
High School & 1 & 1,5 \\
University & 51 & 77,3 \\
Masters & 13 & 19,7 \\
PhD $\quad$ Total & 1 & 1,5 \\
\multicolumn{1}{r|}{$\quad 66$} & 100,0 \\
\hline
\end{tabular}


$77,3 \%$ of participants are university graduates, $19,7 \%$ have masters degree, $1,5 \%$ (1 person each) each are high school and $\mathrm{PhD}$ graduates.

Table 4: The Duty and Title of the Participants

\begin{tabular}{|l|c|c|}
\hline Variable & Titles Distribution & Percent \\
\hline Corporate Communication Manager & 9 & 13,6 \\
\hline Public Relations Manager & 3 & 4,5 \\
\hline Advertising and Public Relations Manager & 3 & 4,5 \\
\hline Press and Public Relations Manager & 3 & 4,5 \\
\hline Public Relations Specialist & 17 & 25,9 \\
\hline Other & 31 & 47,0 \\
\hline Total & 66 & 100,0 \\
\hline
\end{tabular}

$25,9 \%$ of the practitioners who responded the survey call themselves "public relations specialist"; 13,6 \% choose "corporate communication manager", 4,5\% (3 people each) of them equally responded as "public relations manager", "advertising and public relations manager", "press and public relations manager". $47 \%$ chose the other option. Among those who chose other dubbed themselves as "corporate communication administrator", "corporate communication officer" and "corporate communication specialist".

Table 5: Term of Office of the Participants

\begin{tabular}{|l|c|c|}
\hline Variable & $\begin{array}{c}\text { Term of Office in the Organization } \\
\text { Distribution }\end{array}$ & Percent \\
\hline Lower than 1 year & 13 & 19,7 \\
\hline Between 1-3 years & 24 & 36,5 \\
\hline Between 4-6 years & 19 & 28,8 \\
\hline Between 7-9 years & 3 & 4,5 \\
\hline Between 10-13 years & 2 & 3,0 \\
\hline Between 14-17 years & 3 & 4,5 \\
\hline More than 18 years & 2 & 3,0 \\
\hline Total & 66 & 100,0 \\
\hline
\end{tabular}

Among those participants who responded to the question "for how many years do you bear the above mentioned titles in the corporation you work?" $36,5 \%$ of them said that they have been working for 1-3 years, 28,8 \% 4-6 years, 19,7 \% less than 1 year, 4,5 \% (3 people each) equally chose $7-9$ years and $14-17$ years, $3 \%$ (2 people each) equally chose $10-13$ and more than 18 years. 
Table 6: Status of Participant Who Use Social Media Instruments

\begin{tabular}{|l|c|c|}
\hline Variable & Use of Social Media Distribution & Percent \\
\hline Yes & 41 & 62,1 \\
\hline No & 25 & 37,9 \\
\hline Total & 66 & 100,0 \\
\hline
\end{tabular}

Nearly two-thirds of the participants $(62,1 \%)$ use social media tools in their campaigns, activities or organizations related to their social stakeholders compared to those who do not use such tools $(37,9 \%)$.

Table 7: Status of Participants Who Use "Facebook"

\begin{tabular}{|c|c|c|c|}
\hline \multicolumn{2}{|c|}{ Variable } & $\begin{array}{c}\text { Which Instruments Do Participants } \\
\text { Prefer?Distribution }\end{array}$ & Percent \\
\hline \multirow{3}{*}{ Facebook } & Yes & 40 & 97,6 \\
\hline & No & 1 & 2,4 \\
\hline & Total & 41 & 100,0 \\
\hline
\end{tabular}

Nearly all participant $(97,6 \%)$ who use social media tools in their campaigns, activities or organizations related to their social stakeholders use "Facebook" compared to 2,4 \% who do not use them.

Table 8: Status of Participants Who Use "Twitter"

\begin{tabular}{|cccc|}
\hline & \multicolumn{2}{c}{ Which Instruments Do Participants Prefer? } & Percent \\
Variable & Yes & Distribution & 80,5 \\
Twitter & No & 33 & 19,5 \\
& Total & 8 & 100,0 \\
Those who do not use social media & 41 & 25 \\
All those who reply the questionnaire & 66 & \\
\hline
\end{tabular}

Among those 41 participants who use social media tools in their campaigns, activities or organizations related to their social stakeholders $80,5 \%$ of them uses "twitter", $19,5 \%$ mentioned that they do not use it. 
AJIT-e: Online Academic Journal of Information Technology

2013 Fall/Güz - Cilt/Vol: 4 - Sayı/Num: 13

DOI: 10.5824/1309-1581.2013.4.006.x

Table 9: Status of Participants Who Use "LinkedIn"

\begin{tabular}{|c|c|c|c|}
\hline \multicolumn{4}{|c|}{ Which Instruments Do Participants Prefer? } \\
\hline \multirow{4}{*}{ Linkedln } & Variable & Distribution & Percent \\
\hline & Yes & 17 & 41,5 \\
\hline & No & 24 & 58,5 \\
\hline & Total & 41 & 100,0 \\
\hline \multicolumn{2}{|c|}{ Those who do not use social media } & 25 & \\
\hline \multicolumn{2}{|c|}{ All those who reply the questionnaire } & 66 & \\
\hline
\end{tabular}

Among those 41 participants who use social media tools in their campaigns, activities or organizations related to their social stakeholders 41,5\% of them uses "LinkedIn", 58,5\% denoted that they do not use "LinkedIn".

Table 10: Status of Participants Who Use "Youtube"

\begin{tabular}{|cccc|}
\hline & \multicolumn{3}{c|}{ Which Instruments Do Participants Prefer? } \\
& Variable & Distribution & Percent \\
Youtube & No & 13 & 68,3 \\
& Total & 41 & 31,7 \\
Those who do not use social media & 25 & 100,0 \\
All those who reply the questionnaire & 66 & \\
\hline
\end{tabular}

Among those 41 participants who use social media tools in their campaigns, activities or organizations related to their social stakeholders more than two-thirds $68,3 \%$ of them uses "YouTube", 31,7 \% denoted that they do not use "YouTube".

Table 11: Status of Participants Who Use "Blogs"

\begin{tabular}{|c|c|c|c|}
\hline \multicolumn{4}{|c|}{ Which Instruments Do Participants Prefer? } \\
\hline & Variable & Distribution & Percent \\
\hline \multirow{3}{*}{ Blogs } & Yes & 20 & 48,8 \\
\hline & No & 21 & 51,2 \\
\hline & Total & 41 & 100,0 \\
\hline \multicolumn{2}{|c|}{ Those who do not use social media } & 25 & \\
\hline \multicolumn{2}{|c|}{ All those who reply the questionnaire } & 66 & \\
\hline
\end{tabular}


Around half of 41 participants $(48,8 \%)$ who use social media tools in their campaigns, activities or organizations related to their social stakeholders use "blogs", and other half do not use it $(51,2 \%)$.

Table 12: Status of Participants Who Use "Flickr"

\begin{tabular}{|cccc|}
\hline \multicolumn{3}{c}{ Which Instruments Do Participants Prefer? } \\
Vlickr & No & Distribution & Percent \\
Those who do not use social media & 41 & 100 \\
All those who reply the questionnaire & 25 & \\
\hline
\end{tabular}

None of the 41 participants use "Flickr" as a social media tools in their campaigns, activities or organizations related to their social stakeholders.

Table 13: Status of Participants Who Use "Xing"

\begin{tabular}{|cccc|}
\hline \multicolumn{4}{c}{ Which Instruments Do Participants Prefer? } \\
Variable & Distribution & Percent \\
Ying & No & 2 & 4,9 \\
& Total & 39 & 95,1 \\
Those who do not use social media & 41 & 100,0 \\
All those who reply the questionnaire & 25 & \\
\hline
\end{tabular}

Among those 41 participants who use social media tools in their campaigns, activities or organizations related to their social stakeholders 4,9\% of them use "Xing" and 95,1\% do not use it.

Table 14: Status of Participants Who Use "Forums"

\begin{tabular}{|cccc|}
\hline \multicolumn{3}{c}{ Variable } & Dhich Instruments Do Participants Prefer? \\
Forum & No & 16 & Percent \\
& Total & 25 & 39 \\
Those who do not use social media & 41 & 61 \\
All those who reply the questionnaire & 25 & 100,0 \\
\hline
\end{tabular}


Among those 41 participants who use social media tools in their campaigns, activities or organizations related to their social stakeholders $39 \%$ use "forums" and $61 \%$ denoted that they do not use them.

Participants use "Facebook" for their target audiences for various reasons. $11 \%$ (38 people) use it for "content updateability and ease of content publishing". 10,7 \% (37 people each) equally use it for "instant messaging and keeping in touch" and "establishing dialogue between the stakeholder and the corporation". 10,5\% (36 people each) equally use it for "expanding of the target audience" and "getting information from the target audience about the corporation, product/service". 10,1 \% (35 people each) equally uses it for "free access and applications" and "advertising, marketing and publicizing of corporation, product or individual". 9,9\% (34 people) use Facebook for "creating, strengthening and expanding the brand", $9 \%$ (31 people) use it for "networking with professionals in the industry", and 7,6\% (26 people) for "creating new business opportunities". This question was evaluated over more than one answer therefore percentages are calculated on 345 people.

Practitioners give various reasons for using "twitter" for their target audiences: 11,9 \% (33 people) use twitter for "advertising, marketing and publicizing of corporation, product or individual", while 10,9\% (30 people each) of the participants equally use it for "instant messaging and keeping in touch", "content updateability and ease of content publishing", "free access and applications", "establishing dialogue between the stakeholder and the corporation". 9,7\% (27 people) use it for "creating, strengthening and expanding the brand", 9,3\% (26 people) use it for "expanding of the target audience", $9 \%$ (25 people each) equally use it for "networking with professionals in the industry" and "getting information from the target audience about the corporation, product/service", and 7,5\% (21 people) use twitter for "creating new business opportunities". This question was evaluated over more than one answer therefore percentages are calculated on 277 people.

The reason why public relations practitioners use "LinkedIn" has a distribution as such: 11,8 $\%$ (17 people) use "LinkedIn" for "establishing dialogue between the stakeholder and the corporation", 10,4 \% (15 people each) equally use it for "instant messaging and keeping in touch", "content updateability and ease of content publishing", "creating, strengthening and expanding the brand", "networking with professionals in the industry". 11,1\% (16 people) use it for "free access and applications", 9,7\% (14 people each) equally use it for "expanding of the target audience" and "creating new business opportunities". 8,4 \% (11 people) use LinkedIn for "advertising, marketing and publicizing of corporation, product or individual" and $7,7 \%$ use it for "getting information from the target audience about the corporation, product/service". This question was evaluated over more than one answer therefore percentages are calculated on 144 people.

The reasons why participants use "blogs" for their target audiences are shown below: $12 \%$ (20 people) use blogs for "content updateability and ease of content publishing", 11,4 \% (19 people) use it for "expanding of the target audience", and 10,9\% (18 people each) equally use it for "establishing dialogue between the stakeholder and the corporation" and "advertising, marketing and publicizing of corporation, product or individual". 10,2 \% use 
blogs for "creating, strengthening and expanding the brand". 9,7\% (16 people each) equally use blogs for "instant messaging and keeping in touch" and "free access and applications". 9 $\%$ (15 people) use it for "getting information from the target audience about the corporation, product/service", 8,4\% (14 people) for "networking with professionals in the industry", 7,8 $\%$ (13 people) for "creating new business opportunities". This question was evaluated over more than one answer therefore percentages are calculated on 166 people.

Below are the reasons why participants use "YouTube" for their target audiences: 12 \% (27 people each) equally use YouTube for "content updateability and ease of content publishing" and for "free access and applications". 11,5\% (26 people) use it for "advertising, marketing and publicizing of corporation, product or individual", 10,6 \% (24 people each) equally use for "establishing dialogue between the stakeholder and the corporation" and for "creating, strengthening and expanding the brand". 10,2 \% (23 people) use YouTube for "expanding of the target audience"; 9,7\% (22 people) use it for "getting information from the target audience about the corporation, product/service"; 9,3\% (21 people) use it for "instant messaging and keeping in touch", 8,4 \% (19 people) use it for "networking with professionals in the industry", and 5,7 \% (13 people) use YouTube for "creating new business opportunities". This question was evaluated over more than one answer therefore percentages are calculated on 226 people.

Participants use "Xing" for their target audiences for the following reasons: 11,8 \% (2 people each) equally use it for "instant messaging and keeping in touch", "content updateability and ease of content publishing", "free access and applications", "establishing dialogue between the stakeholder and the corporation", "creating, strengthening and expanding the brand", "networking with professionals in the industry" and for "creating new business opportunities". 5,8 \% (1 person each) use Xing for "advertising, marketing and publicizing of corporation, product or individual", "expanding of the target audience", "getting information from the target audience about the corporation, product/service". This question was evaluated over more than one answer therefore percentages are calculated on 17 people.

Participants use "Forums" for their target audiences for the following reasons: 11,8 \% (2 people each) equally use it for "instant messaging and keeping in touch", "content updateability and ease of content publishing", "free access and applications", "establishing dialogue between the stakeholder and the corporation", "creating, strengthening and expanding the brand", "networking with professionals in the industry" and for "creating new business opportunities". 5,8 \% (1 person each) use forums for "advertising, marketing and publicizing of corporation, product or individual", "expanding of the target audience", "getting information from the target audience about the corporation, product/service". This question was evaluated over more than one answer therefore percentages are calculated on 17 people. 
Table 15: Frequency of Participants' Use of "Facebook"

\begin{tabular}{|lcc|}
\hline & How Often Facebook is Used \\
Variable & Distribution & Percent \\
Everyday & 24 & 58,6 \\
Once in 1-3 days & 6 & 14,6 \\
Once in 3-5 days & 9 & 22,0 \\
When Necessary & 1 & 2,4 \\
Never & 1 & 2,4 \\
Total & 41 & \\
Those who do not use social media & 25 & \\
Grand Total & 66 & 100,0 \\
\hline
\end{tabular}

Participants were asked how often they use "Facebook", which is one of the social media tools that they make use of it for their target audience, and 58, $6 \%$ use Facebook everyday, $22 \%$ use it once in 3-5 days, $14,6 \%$ use it once in 1-3 days, 2,4 \% (1 person each) never uses Facebook or uses it when it is necessary.

Table 16: Frequency of Participants' Use of "Twitter"

\begin{tabular}{|lcc|}
\hline & How Often Twitter is Used & \\
Variable & Distribution & Percent \\
Everyday & 16 & 39,0 \\
Once in 1-3 days & 8 & 19,5 \\
Once in 3-5 days & 8 & 19,5 \\
When Necessary & 2 & 4,9 \\
Never & 7 & 17,1 \\
Total & 41 & 100,0 \\
Those who do not use social media & 25 & \\
Grand Total & 66 & \\
\hline
\end{tabular}

Participants were asked how often they use "Twitter", which is one of the social media tools that they make use of it for their target audience, and 39\% use it everyday, 19,5\% (9 people each) equally use it once in 1-3 days and once in 3-5 days, 4,9\% use it when it is necessary and $17,1 \%$ never use Twitter. 
Table 17: Frequency of Participants' Use of "Youtube"

\begin{tabular}{|lcc|}
\hline \multicolumn{1}{|c|}{ How Often Youtube is Used } & \\
Variable & Distribution & Percent \\
Everyday & 3 & 7.3 \\
Once in 1-3 days & 4 & 9.8 \\
Once in 3-5 days & 2 & 4.9 \\
Once in a week & 1 & 2.4 \\
When necessary & 26 & 63.4 \\
Never & 5 & 12.2 \\
Total & 41 & \\
Those who do not use social media & 25 & 100,0 \\
Grand Total & 66 & \\
\hline
\end{tabular}

Participants were asked how often they use "YouTube", which is one of the social media tools that they make use of it for their target audience, and 63,4 \% use it when it is necessary, 9,8 \% use it once in 1-3 days, 7,3\% use it everyday, 4,9\% use YouTube once in 3-5 days, 2,4 $\%$ uses it once in a week, and $12,2 \%$ never use YouTube.

Table 18: Frequency of Participants' Use of "Blogs"

\begin{tabular}{|lcc|}
\hline & How Often Youtube is Used & \\
Variable & Distribution & Percent \\
Once in 1-3 days & 2 & 4,9 \\
Once in 3-5 days & 2 & 4,9 \\
Once in a week & 1 & 2,4 \\
When Necessary & 15 & 36,6 \\
Never & 21 & 51,2 \\
Total & 41 & 100,0 \\
Those who do not use social media & 25 & \\
Grand Total & 66 & \\
\hline
\end{tabular}

Participants were asked how often they use "blogs", which is one of the social media tools that they make use of it for their target audience, and 36,6 \% (15 people) use blogs when necessary, 4,9\% (2 people each) equally use them once in 1-3 days and once in 3-5 days, 2,4 $\%$ use blogs once in a week, half of the participants never use blogs (21 people, 51,2 \%). 
Table 19: Frequency of Participants' Use of "Flickr"

\begin{tabular}{|c|c|c|}
\hline \multicolumn{3}{|c|}{ How Often Flickr is Used } \\
\hline Variable & Distribution & Percent \\
\hline Never & 41 & 100,0 \\
\hline Total & 41 & 100,0 \\
\hline Those who do not use social media & 25 & \\
\hline Grand Total & 66 & \\
\hline
\end{tabular}

Participants were asked how often they use "Flickr", which is one of the social media tools that they make use of it for their target audience, they stated that they do not use "Flickr".

Table 20: Frequency of Participants' Use of "LinkedIn"

\begin{tabular}{|lcc|}
\hline \multicolumn{2}{c}{ Vow Often LinkedIn is Used } & \\
Everyday & Distribution & Percent \\
Once in 1-3 days & 5 & 12,2 \\
Once in a week & 2 & 4,9 \\
When Necessary & 1 & 2,4 \\
Never & 11 & 26,8 \\
Total & 22 & 53,7 \\
Those who do not use social media & 41 & 100,0 \\
Grand Total & 25 & \\
\hline
\end{tabular}

Participants were asked how often they use "LinkedIn", which is one of the social media tools that they make use of it for their target audience, 26,8 \% use LinkedIn when necessary, $12,2 \%$ use it everyday, $4,9 \%$ use it once in 1-3 days, $2,4 \%$ use it once in a week, half of the participants responded that they never use LinkedIn (53,7\%).

Table 21: Frequency of Participants' Use of "Forums"

\begin{tabular}{|lcc|}
\hline \multicolumn{2}{|c|}{ How Often Forums are Used } & \\
Variable & Distribution & Percent \\
Once in a week & 2 & 4,9 \\
When necessary & 19 & 46,3 \\
Never & 20 & 48,8 \\
& & \\
Total & & 100,0 \\
Those who do not use social media & 41 & \\
Grand Total & 25 & \\
\hline
\end{tabular}


Participants were asked how often they use "forums", which is one of the social media tools that they make use of it for their target audience, nearly half of them $(46,3 \%)$ use them when necessary, $4,9 \%$ equally use them once in a week the other half $(48,8 \%)$ admit that they never use forums.

Table 22: Frequency of Participants' Use of "Xing"

\begin{tabular}{|lcc|}
\hline Variable & $\begin{array}{c}\text { How Often Xing is Used } \\
\text { Distribution }\end{array}$ & Percent \\
& & \\
Once in 1-3 days & 1 & 2,4 \\
Once in a week & 1 & 2,4 \\
When Necessary & 5 & 12,2 \\
Never & 34 & 83 \\
Total & 41 & 100,0 \\
Those who do not use social media & 25 & \\
Grand Total & 66 & \\
\hline
\end{tabular}

Participants were asked how often they use "forums", which is one of the social media tools that they make use of it for their target audience, 12,2\% use Xing when necessary, 2,4 \% (1 person each) equally use it once in 1-3 days and once in a week, and $83 \%$ never use Xing.

When participants were asked to list the social media tools according to their importance "Strengthening corporate identity and reputation" takes the first rank with 70,7 \% (29 people). The second rank is taken by "establishing and maintaining interactivity with different groups" with 48,8 \% (20 people). Third rank goes to "obtaining ideas quickly about the organization" with $43,9 \%$ (18 people). Fourth place is occupied by "reducing the market research expenditures" with $39 \%$ (16 people). "Creating the opportunity of word of mouth marketing" occupies the fifth place with $46,3 \%$ (19 people) and "gaining new customers" takes the sixth place with $39 \%$ (16 people). Seventh place is occupied by "promoting brand awareness" with 48,8\% (20 people). "Making the organization more visible in social media" took the eighth place with $43,9 \%$ (18 people). Ninth place is taken by "being able to compete with the competitors in this field" with $48,8 \%$ (20 people). "Following the competitors" occupies the tenth place with 56,1 \% (23 people), and "informing the social stakeholders" (about the organizations' products and services, and about innovations and developments about the corporation) took the eleventh place with $41,5 \%$ (17 people).

When the agreement level of participants to the statement "I prefer social media tools to traditional media tools" is questioned, 36,6 \% (15 people) responded as "I agree", 26,8 \% (11 people) says "I do not agree", $22 \%$ (9 people) do not have any idea about it, and 14,6 \% (6 people) responded as "I certainly agree". 
When the agreement level of participants to the statement "Social media tools replace traditional media tools" is questioned, 43,9\% (18 people) did not agree with this statement. 36,6 \% (15 people) responded as "I agree", 17,1 \% (7 people) says "I certainly agree", 2,4 \% (1 person) do not have any idea about this statement.

When the agreement level of participants to the statement "Social media tools are tools that only supports traditional media tools" is questioned, 63,4 \% (26 people) responded as "I agree", $22 \%$ (9 people) did not agree with the statement, 9,7\% (4 people) certainly agreed and $4,9 \%$ (2 people) did not have any idea about this question.

When the agreement level of participants to the statement "Social media created new target groups and these groups are new stakeholder groups for public relations" is questioned, 65,9 $\%$ (27 people) responded as "I agree", 24,4 \% (10 people) certainly agreed with the statement, $7,3 \%$ ( 3 people) do not have any idea about this question and 2,4\% ( 1 person) did not agree with the statement.

When the agreement level of participants to the statement "Social media tools create opportunity to establish direct communication and interaction with the social stakeholders" is questioned, $63,4 \%$ (26 people) agreed with the statement, 31,7 \% (13 people) certainly agreed and $4,9 \%$ ( 2 people) did not have any idea about this question.

When the agreement level of participants to the statement "In our relations with social networks our main goal as a corporation is to keep contact with our new target audiences" is questioned, 75,6\% (31 people) agreed with the statement, 14,6\% (6 people) certainly agreed and $9,8 \%$ (4 people) did not agree with the statement.

When the agreement level of participants to the statement "Social networks are important public relations tools where two-way communication is attained only if feedback processes run correctly" is questioned, 68,3\% (28 people) agreed with the statement, $26,9 \%$ (11 people) certainly agreed and 2,4 \% (1 person each) equally responded as "I do not have any idea about it" and "I certainly disagree".

When the agreement level of participants to the statement "We share audio-visual content (i.e. the opening speech of the general manager, the new product announcement video dubbed by the sales marketing manager) that belongs to our corporation via social network sites with our stakeholders" is questioned, $61 \%$ (25 people) agreed with the statement, 19,5 $\%$ (8 people) certainly agreed, 12,2 \% (5 people) disagreed and 7,3\% (3 people) do not have any idea about it.

When the agreement level of participants to the statement "Through social network sites a personal relationship began between our corporation and our stakeholders" is questioned, $65,9 \%$ (27 people) agreed with the statement, $22 \%$ (9 people) certainly agreed, 9,7 \% (4 people) disagreed and 2,4\% (1 person) do not have any idea about it. 
When the agreement level of participants to the statement "Through social media tools we receive the messages of our stakeholders related to our corporation, our brands, our products and services and we give feedback" is questioned, $61 \%$ ( 25 people) agreed with the statement, $24,4 \%$ (10 people) certainly agreed, 9,7\% (4 people) do not have any idea about it, $4,9 \%$ (2 people) disagreed.

When the agreement level of participants to the statement "We care for and evaluate user comments, wishes, expectations and complaints in social media tools" is questioned, 58,5\% (24 people) agreed with the statement, 31,7 \% (13 people) certainly agreed, 4,9\% (2 people each) equally responded as "I do not have any idea about it" and "I certainly disagree".

When the agreement level of participants to the statement "We statistically analyze the rate of our corporation's social media follow-up and reading rates" is questioned, 65,9\% (27 people) agreed with the statement, 29,3 \% (12 people) certainly agreed, 2,4 \% (1 person each) equally responded as "I do not have any idea about it" and "I certainly disagree".

When the agreement level of participants to the statement "Not to take part in the social media as a corporation may give us disadvantages before our rivals" is questioned, 65,9\% (27 people) agreed with the statement, $17 \%$ (7 people) certainly agreed, 9,8\% (4 people) disagree and $7,3 \%$ (3 people) do not have an idea about it.

When the agreement level of participants to the statement "Not to take part in the social media as a corporation or that they cannot manage it causes crisis" is questioned, 53,7 \% (22 people) agreed with the statement, $39 \%$ (16 people) certainly agreed, 7,3 \% (3 people) do not have an idea about it.

When the agreement level of participants to the statement "I saw social media tools both an opportunity and a threat for corporations in their communication with their social stakeholders" is questioned, 70,8 \% (29 people) agreed with the statement, 14,6 \% (6 people) disagree, 9,8 \% (4 people) certainly agree, 2,4\% (1 person each) equally responded as "I do not have any idea" and "I certainly disagree".

\section{CONCLUSION}

According to the survey results, the number of public relations practitioners who use social media tools in their activities or organizations related to their social stakeholders cannot be underestimated. The practitioners use Facebook the most. The public relations practitioners who use social media tools, took on that Facebook, which has nearly 1 billion members, has an important role in the transmission of products and services to be taken to the customer without big marketing and advertising budgets and it is an important and effective tool used in corporations' activities or organizations related to their social stakeholders. The practitioners who use Facebook agreed on the facts that content updateability and ease of content publishing, instant messaging and keeping in touch and establishing dialogue between the stakeholder and the corporation are the reasons why they use Facebook. 
"Strengthening corporate identity and reputation" took the first place in the ranking made according to its importance degree of the intended purposes of social media tools which participants took advantage of them for their target audiences. Social media tools are able to create a climate of thought relating to a specific event, person, corporation, etc. with their large dialogue environment and with their power to forge public opinion. Creating a positive climate of thought may bring an environment of trust and esteem whereas the opposite situation may drag the corporation to a crisis and prepare its destruction. In this sense, it can be said that participants reconciled upon the power of social media tools which have a global influence over the corporations.

When participants' views are asked on social media and traditional media, it occurs that most of them prefer social media tools to traditional media tools. When participants' views are asked whether social media tools took the place of traditional media tools, those who think social media did not displace traditional media are more common, however they are proportionally equal. It is revealed that there is a consensus that social media tools support the traditional media tools. It is possible to deduce that even though participants prefer social media to traditional media, they want to make use of them both according to their needs.

Participants are of the same opinion that social media creates new target groups and that these target groups form a new stakeholder group. They are also of the same opinion that social media tools create an opportunity to establish direct communication and interaction with the social stakeholders.

Participants are of the same opinion that through social network sites they share audiovisual contents with their stakeholders and that through these sites corporations began to have a personal communication with their social stakeholders.

Participants are also of the same opinion that through the social media tools they receive the messages of their stakeholders related to their corporation, their brands, their products and services and that they consider their stakeholders' comments, wishes, expectations and complaints seriously and give feedback accordingly.

The corporations settled on that they statistically analyze the rate of their corporation's social media follow-up and reading rates. An analysis of this type, help them to gain consciousness about the number of their followers and to what extent they convey their messages to their target audiences.

Participants are of the same opinion that if they do not take part in the social media they would be dragged into a disadvantaged position before their rivals. They are also of the same opinion that if they do not take part in the social media or if they cannot manage it right may cause crisis.

The proportional majority of the participants see social media tools both an opportunity and a threat in corporation's communication with their social stakeholders. Accordingly, 
participants think that corporations will get the best if they direct their corporate strategies considering the ideas of the target audience in the dialogue environment provided by the two-way communication of social media tools. However, social media tools are also seen as a threat because they have the feature of spreading negative rumors quickly around the globe and they would cause a catastrophe if they are not followed or controlled by the corporations.

As a result, the active use of social media tools, which have the power to create public opinion, and the following of social network sites meticulously by public relations practitioners, will help them to have a command on this large market formed by online communities. Thus corporations, in line with the data that they obtained, can create investment, publicity and sales strategies as to achieve maximum efficiency and they may contribute to the fulfillment of the needs of the target audience.

\section{REFERENCES}

Akar E (2011) Sosyal Medya Pazarlaması. Sosyal Webde Pazarlama Stratejileri, Efil Yayınevi, Ankara.

Aşman Alikılıç Ö (2011) Halkla İlişkiler 2.0. Sosyal Medyada Yeni Paydaşlar, Yeni Teknikler, Efil Yayınevi.

Bradley P (2010) Be Where The Conversations Are: The Critical Importance of Social Media, Business Information Review, 27 (4), p. 250.

Brown R (2009) Public Relations and The Social Web, Kogan Page, London.

Fuchs C (2008) Internet and Society: Social Theory in the Information Age, Routledge, New York.

Herring, Susan C., (et al), "Weblogs as a Bridging Genre", http://portal.colman.ac.il/users/www/86/Weblogs.pdf, Erişim Tarihi, 03.09.2009

Onat F., Aşman Alikılıç Ö (2008) Sosyal Ağ Sitelerinin Reklam ve Halkla İlişkiler Ortamları Olarak Değerlendirilmesi, Journal of Yaşar University, 3(9), pp. 1134-1135.

Öymen Dikmen G (2011) Tüketen Üreticiden Üreten Tüketiciye Dönüşümde Sosyal Medyanın Rolü, İletişim ve Teknoloji. Olanaklar, Uygulamalar, Sınırlar, Kırmızı Kedi Yayınevi, İstanbul.

Özgen E (2012) Sosyal Medya ve Halkla İlişkilerde Değişen Medya Anlayışı, Sosyal Medya/Akademi, Beta Yayınları, İstanbul. 
AJIT-e: Online Academic Journal of Information Technology

2013 Fall/Güz - Cilt/Vol: 4 - Sayı/Num: 13

DOI: 10.5824/1309-1581.2013.4.006.x

Sayımer İ (2008) Sanal Ortamda Halkla İlişkiler, Beta Yayınları, İstanbul.

http://press.linkedln.com/about, Erişim Tarihi: 27 Haziran 2012.

http://www.flickr.com/, Erişim Tarihi: 27.06.2012.

http://www.xing.com/tr, Erişim Tarihi: 27.06.2012. 